\title{
BANK OWNERSHIP, MODE OF ENTRY, AND CREDIT ALLOCATION TO MSMES
}

\author{
Rahmat Setiawan', Octavia Reniar Putri², Rosmiati Jafar ${ }^{3}$ \\ ${ }^{1}$ rahmatsetiawan@feb.unair.ac.id \\ Airlangga University \\ Jl. Airlangga No.4 - 6, Airlangga, Kec. Gubeng, Kota SBY, Jawa Timur
}

received: 21/6/19; revised: 6/6/20; approved: 28/6/21

\begin{abstract}
Micro, small, and medium enterprises (MSMEs) have strategic roles in economic structure, especially in developing countries, so, they need supports from the banking industry, including foreign banks, by giving loans they need. This study aims to find the effect of bank ownership and mode of entry on credit allocation to MSMEs. We use 110 samples of conventional commercial banks and 41 samples of foreign-owned banks in Indonesia during 2010-2017, with 686 and 266 observations. The results of multiple regression show that banks with government ownership have higher credit allocation to MSMEs than non-government ownership and banks with foreign ownership have lower credit allocation to MSMEs than domestic ownership. Based on their mode of entry, banks with foreign ownership via greenfield have lower credit allocation to MSMEs than via takeover.
\end{abstract}

Keywords: banks; ownership; mode of entry; credit allocation; MSMEs

\section{INTRODUCTION}

The development of micro, small and medium enterprises (MSMEs) is vital for national economic growth. MSMEs are the main sources of employment for the nation and contribute significantly to a country's economy (Eze et al., 2021). Several studies showed that MSMEs have strategic roles in economic structure, especially in developing countries, such as Indonesia. MSMEs usually face many financial constraints (as opposed to large companies which usually have more opportunities to obtain external financing), this is because creditors face difficulties in accessing information about MSMEs (Cariola et al., 2020). To overcome this problem, the government through Bank Indonesia Regulation (PBI) No. 17/12/PBI/2015 requires banks, including foreign banks, to increase their credit allocation to MSMEs, namely 5\% in 2015, 10\% in 2016, $15 \%$ in 2017, and 20\% in 2018. From this regulation, we can find out how important MSMEs are in Indonesia. Bank's credit allocation to MSMEs in Indonesia grows every year and the growth is higher than total credit in the banking industry in general. Figure 1 shows that MSMEs credit growth in Indonesia increases from 2012 until 2017 and the growth in 2017 is the highest.

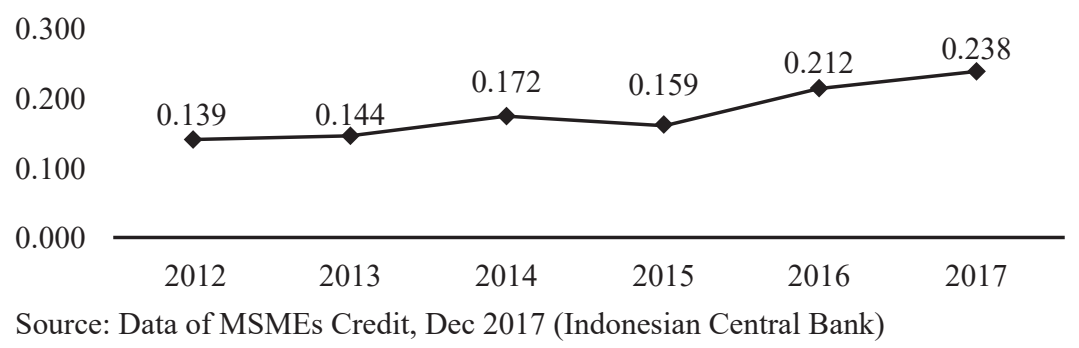

Figure 1. MSMEs Credit Growth

The existence of foreign banks and ownership has been debatable, considering its advantages and disadvantages (Lubis, et al., 2015). Foreign investors in Indonesia are allowed to own bank shares up to $99 \%$ based on Government Regulations No 29 in 1999. This high foreign participation hopefully could increase total credit allocation to MSMEs in the banking industry and give an advantage to economies in the country, however, 
there are a few studies that showed that foreign banks tend to allocate credits to transparent borrowers only and ignore opaque borrowers, like MSMEs.

The type of bank ownership is one of the main factors influencing credit allocation decisions made by banks. The main reason behind the importance of the role of ownership type is that the type of ownership will determine the main motivation in the way a bank to manage their business (Çolak \& Şenol, 2021). This is also supported by the Banking Industry Profile Report Quarter IV 2017 also showed that based on bank ownership, credit allocation to MSMEs is mostly given by state-owned banks $(56.08 \%)$, private domestic banks (35.13\%), regional development banks $(7.97 \%)$, and then followed by foreign-owned banks and joint-venture banks $(0.82 \%)$. Figure 2 shows that banks with government ownership have the highest MSMEs credit growth and banks with foreign ownership have the lowest MSMEs credit growth.

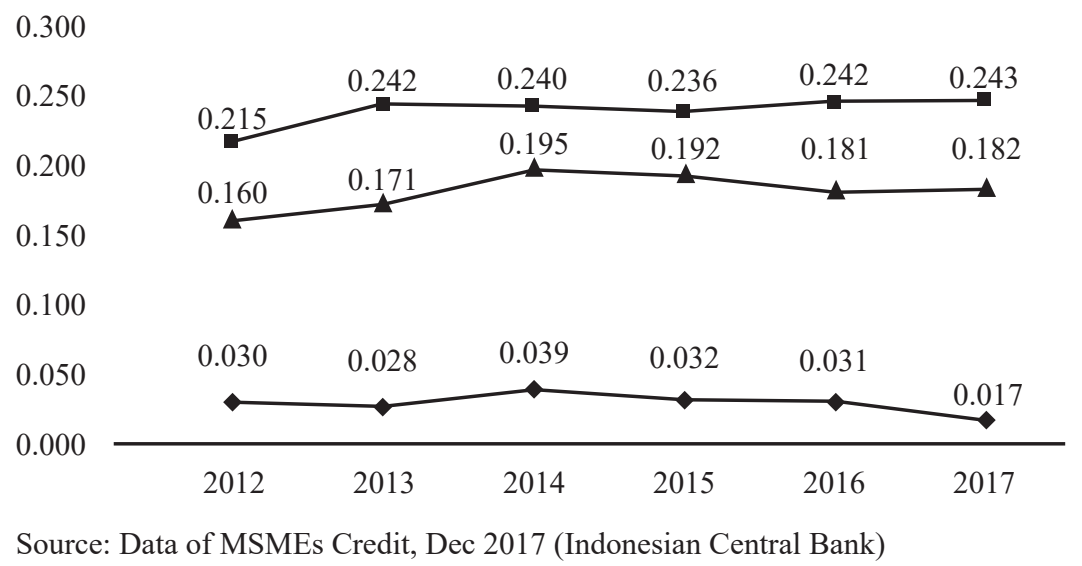

Figure 2. MSMEs Credit Growth based on Ownership

Banks can be grouped into many types. In this study, we use 3 groups of banks based on their ownership, which are banks with government ownership, private domestic ownership, and foreign ownership. However, based on Guidance Book for Central Government Content (2013:32), there are 5 types of conventional commercial banks in Indonesia, such as state-owned banks, foreign exchange commercial banks, non-foreign exchange commercial banks, regional development banks, joint venture banks, and foreign-owned banks.

State-owned banks are banks that all or most of the shares are owned by the government, so they are included in the group of banks with government ownership. Foreign exchange and non-foreign exchange commercial banks are banks that all or most of the shares are owned by private domestic investors, so they are included in the group of banks with private domestic ownership. Regional development banks are banks with all or most of the shares are owned by the regional government, so they are included in the group of banks with government ownership. Joint venture banks are banks that shares are owned by private domestic and foreign investors, so they are included in the group of foreign ownership if there are more than $50 \%$ of the shares owned by foreign investors. Foreign-owned banks are banks that all of the shares are owned by foreign investors, so they are included in the group of banks with foreign ownership.

Foreign ownership itself can be differentiated by their mode of entry or how foreign investors enter domestic banking markets, which are greenfield and takeover. Banks with foreign ownership via greenfield are banks that enter domestic banking markets by doing greenfield investing or directly open new branch offices or subsidiaries in the host country with shares more than $50 \%$. While banks with foreign ownership via takeover are banks that enter domestic banking markets by doing a takeover process on domestic banks with shares more than $50 \%$ (DeGryse et al., 2012).

One of the main activities of the banking industry is to allocate credits to borrowers. This credit allocation can be viewed by their type of borrowers and borrower transparency. Based on this, credit allocation to Micro, Small, and Medium Enterprises (MSMEs) is interesting to be tested, because we could see the role of information for banks in the decision of this credit allocation. Credit allocation to MSMEs is credit allocated by banks to the borrowers that are opaque (not transparent) because their accounting information is so little and it is hard for banks to evaluate them. Banks could only evaluate them based on soft information, such as their business, owner, and management information (Dell' Ariccia and Marquez, 2004).

Banks with government ownership have higher credit allocation to MSMEs than non-government ownership because these banks are influenced by the government's consideration to provide subsidized loans (DeGryse et al., 2012). They have another objective besides maximizing profits, namely social objectives (Berger et al., 2004), so 
MSMEs could obtain adequate financing to expand their businesses. They also have better access to MSMEs, so they allocate more credits to MSMEs than banks with non-government ownership (Berger et al., 2001).

Banks with foreign ownership have lower credit allocation to MSMEs than domestic ownership, because these banks have to face information weaknesses and therefore, they prefer to target clients that are more transparent and have lower credit allocation to MSMEs than banks with domestic ownership because they have high asymmetry information (Dell' Aricia and Marquez, 2004; Sengupta, 2007; Detragiache et al., 2008; Althammer and Haselmann, 2011; Gormley, 2014). If these banks could get soft information, they might have difficulties or are less willing to communicate it to the parent bank (DeGryse et al., 2012). These banks also have a screening advantage. Their screening technology is better than domestic banks to evaluate their borrowers and therefore they tend to ignore borrowers that have high asymmetry information like MSMEs (Boustanifar, 2014).

Banks with foreign ownership via greenfield have lower credit allocation to MSMEs than via takeover because these banks are facing larger information disadvantage, so they will only rely on hard information to analyze their borrowers' creditworthy, while banks with foreign ownership via takeover have incumbency advantage, which makes them have the customer base and could use soft information in addition to financial reports, and therefore these banks will still maintain riskier borrowers from the previous domestic banks (Claeys and Heinz, 2014).

Most of previous studies that addressed many issues of bank ownership structure only focused on the effect of bank ownership structure on risk and performance (Ding et al., 2020; Luu et al., 2020), while studies about bank ownership and mode of entry on bank credit allocation to MSMEs are still limited, especially in Indonesia. Therefore, this study is intended to fill in the research gap by providing an analysis of the relationship between bank ownership, mode of entry, and credit allocation to MSMEs. This research is also the first research that discusses the allocation of bank credit to MSMEs in a comprehensive manner. The objective of this study was to use bank-level information to determine if banks with government ownership have higher credit allocation to MSMEs than non-government ownership and foreign ownership have lower credit allocation to MSMEs than banks with domestic ownership and if banks with foreign ownership via greenfield have lower credit allocation to MSMEs than via takeover.

\section{METHODS}

To examine the impact of bank ownership and mode of entry on credit allocation to MSMEs, the author estimates the following model:

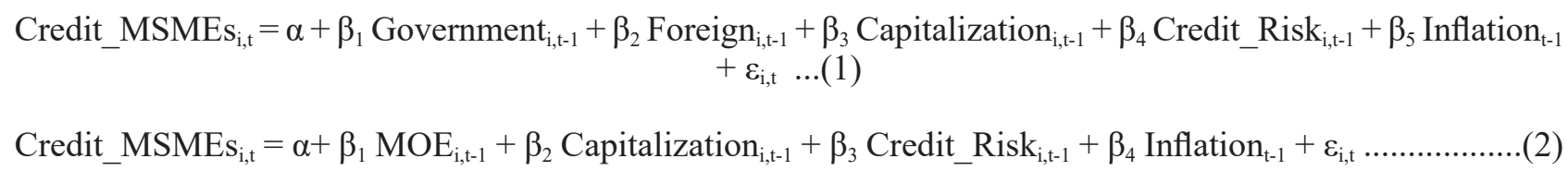

where:

$\alpha \quad=$ Intercept from regression models

$\beta \quad=$ Coefficient from each variable on the regression models

Credit_MSMEs $\mathrm{S}_{\mathrm{i}, \mathrm{t}}=$ Credit allocation to MSMEs of bank $\mathrm{i}$ at time $\mathrm{t}$

Government $_{i, t-1}=$ Dummy variable for government ownership of bank $i$ at time $t-1$, which takes the value of 1 if more than $50 \%$ of the bank is owned by government and 0 if more than $50 \%$ of the bank is owned by non-government.

Foreign $_{\mathrm{i}, \mathrm{t}-\mathrm{1}} \quad=$ Dummy variable for foreign ownership of bank $\mathrm{i}$ at time $\mathrm{t}-1$, which takes the value of 1 if more than $50 \%$ of the bank is owned by foreign investors and 0 if more than $50 \%$ of the bank is owned by domestic investors.

$\mathrm{MOE}_{\mathrm{i}, \mathrm{t}-1} \quad=$ Mode of Entry is dummy variable for banks with foreign ownership based on their mode of entry of bank $i$ at time $t-1$, which takes the value of 1 if foreign investor enter the market via greenfield with more than $50 \%$ of the bank shares and 0 if foreign investor enter the market via takeover with more than $50 \%$ of the bank shares.

Capitalization $_{\mathrm{i}, \mathrm{t}-1}=$ Capitalization of bank i at time $\mathrm{t}-1$ as a control variable (Measured by Capital Adequacy Ratio)

Credit_Risk $\mathrm{i}_{\mathrm{i}, \mathrm{-}}=$ Credit risk of bank $\mathrm{i}$ at time $\mathrm{t}-1$ as a control variable (Measured by the ratio of NonPerforming Loans to total loans)

Inflation $_{\mathrm{t}-1} \quad=$ Inflation rate at time $\mathrm{t}-1$ as a control variable

$\varepsilon_{\mathrm{i}, \mathrm{t}} \quad=$ Error term of bank i at time $\mathrm{t}$ 
In order to estimate the multiple regression model, the author used 110 samples of conventional commercial banks (for model 1) and 41 samples of foreign-owned banks (for model 2) in Indonesia during 2010-2017, with 686 observations for model 1 and 266 observations for model 2. The data are from Financial Services Authority and Indonesian Central Bank database, and also directly from the respective bank's annual financial report.

\section{RESULTS}

Table 1 reports that on average, all banks allocated 27.3 percent of their credit to MSMEs and all foreign banks allocated 12.3 percent of their credit to MSMEs. In addition, 18 percent of the banking industry is owned by the government, and 39 percent of the banking industry is owned by foreign investors and based on their mode of entry, 49 percent of all foreign banks entering banking markets via greenfield.

Table 1. Descriptive Statistics

\begin{tabular}{|c|c|c|c|c|c|}
\hline & $\mathrm{N}$ & Mean & Std. Dev & Min. & Max. \\
\hline \multicolumn{6}{|c|}{ Credit_MSMEs } \\
\hline Model 1 & 686 & 0.273 & 0.252 & 0.000 & 0.995 \\
\hline Model 2 & 266 & 0.123 & 0.148 & 0.000 & 0.798 \\
\hline Government & 686 & 0.180 & 0.381 & 0.000 & 1.000 \\
\hline Foreign & 686 & 0.390 & 0.488 & 0.000 & 1.000 \\
\hline MOE & 266 & 0.490 & 0.501 & 0.000 & 1.000 \\
\hline \multicolumn{6}{|c|}{ Capitalization } \\
\hline Model 1 & 686 & 0.255 & 0.193 & 0.000 & 1.814 \\
\hline Model 2 & 266 & 0.307 & 0.250 & 0.000 & 1.814 \\
\hline \multicolumn{6}{|l|}{ Credit_Risk } \\
\hline Model 1 & 686 & 0.024 & 0.028 & 0.000 & 0.376 \\
\hline Model 2 & 266 & 0.024 & 0.030 & 0.000 & 0.339 \\
\hline \multicolumn{6}{|l|}{ Inflation } \\
\hline Model 1 & 686 & 0.051 & 0.022 & 0.028 & 0.084 \\
\hline Model 2 & 266 & 0.051 & 0.022 & 0.028 & 0.084 \\
\hline
\end{tabular}

Moreover, we show the results of the Pearson correlation in this study. Pearson correlation is a correlation measure used to measure the strength and direction of a linear relationship between two variables. Table 2 shows that the government ownership has a significant positive correlation with credit allocation to MSMEs at a significance level of $1 \%$. Foreign ownership has a significant negative correlation with credit allocation to MSMEs at a significance level of $1 \%$. Credit risk has a significant negative correlation with credit allocation to MSMEs with a significance level of $10 \%$. Capitalization and inflation have no significant negative correlation with credit allocation to MSMEs. Meanwhile, Table 3 shows that the mode of entry has a significant negative correlation with credit allocation to MSMEs at a significance level of $1 \%$. Capitalization, credit risk and inflation has no significant positive correlation with credit allocation to MSMEs.

Table 2. Pearson Correlation (Model 1)

\begin{tabular}{|c|c|c|c|c|c|c|}
\hline & Credit MSMEs & Government & Foreign & Capitalization & Credit Risk & Inflation \\
\hline Credit MSMEs & 1.000 & & & & & \\
\hline Government & $\begin{array}{c}0.226^{* * *} \\
(0.000)\end{array}$ & 1.000 & & & & \\
\hline Foreign & $\begin{array}{c}-0.472 * * * \\
(0.000)\end{array}$ & $\begin{array}{c}-0.369 * * * \\
(0.000)\end{array}$ & 1.000 & & & \\
\hline Capitalization & $\begin{array}{l}-0.031 \\
(0.212)\end{array}$ & $\begin{array}{c}-0.175 * * * \\
(0.000)\end{array}$ & $\begin{array}{c}0.219 * * * \\
(0.000)\end{array}$ & 1.000 & & \\
\hline Credit Risk & $\begin{array}{l}-0.056^{*} \\
(0.071)\end{array}$ & $\begin{array}{c}0.105^{* * * *} \\
(0.003)\end{array}$ & $\begin{array}{c}0.003 \\
(0.468)\end{array}$ & $\begin{array}{c}0.002 \\
(0.474)\end{array}$ & 1.000 & \\
\hline Inflation & $\begin{array}{l}-0.022 \\
(0.286)\end{array}$ & $\begin{array}{l}-0.006 \\
(0.443)\end{array}$ & $\begin{array}{l}-0.009 \\
(0.412)\end{array}$ & $\begin{array}{l}-0.058^{*} \\
(0.066)\end{array}$ & $\begin{array}{c}-0.141 * * * \\
(0.000)\end{array}$ & 1.000 \\
\hline
\end{tabular}

Sign $* * * * *$, and $*$ present significance at the $1 \%, 5 \%$, and $10 \%$ level.

Numbers in parenthesis is p-value 
Table 3. Pearson Correlation (Model 2)

\begin{tabular}{|c|c|c|c|c|c|}
\hline & Credit MSMEs & $\mathrm{MOE}$ & Capitalization & Credit Risk & Inflation \\
\hline Credit MSMEs & 1.000 & & & & \\
\hline MOE & $\begin{array}{c}-0.464 * * * \\
(0.000)\end{array}$ & 1.000 & & & \\
\hline Capitalization & $\begin{array}{c}0.063 \\
(0.154)\end{array}$ & $\begin{array}{l}0.093 * \\
(0.065)\end{array}$ & 1.000 & & \\
\hline Credit Risk & $\begin{array}{l}-0.057 \\
(0.178)\end{array}$ & $\begin{array}{l}-0.071 \\
(0.123)\end{array}$ & $\begin{array}{c}0.120 * * \\
(0.026)\end{array}$ & 1.000 & \\
\hline Inflation & $\begin{array}{l}-0.014 \\
(0.408)\end{array}$ & $\begin{array}{c}0.012 \\
(0.420)\end{array}$ & $\begin{array}{l}-0.067 \\
(0.138)\end{array}$ & $\begin{array}{c}-0.199 * * * \\
(0.001)\end{array}$ & 1.000 \\
\hline
\end{tabular}

Sign $* * *, * *$, and $*$ present significance at the $1 \%, 5 \%$, and $10 \%$ level.

Numbers in parenthesis is p-value.

The results of the regression analysis based on Table 4 column 1 show that the dummy variable Government $t_{\mathrm{i}, \mathrm{t}-1}$ have a significant positive effect on Credit_MSMEs $\mathrm{i}_{\mathrm{i}, \mathrm{t}}$, while Foreign $\mathrm{i}_{\mathrm{i}, \mathrm{-}-\mathrm{p}}$ have a significant negative effect on Credit_MSMEs $\mathrm{i}_{\mathrm{i}, \mathrm{t}}$. And when we also inputted our control variables (capitalization, credit risk, and inflation), the results in column 2 remain the same. It shows that banks with government ownership have higher credit allocation to MSMEs than non-government ownership and foreign ownership has lower credit allocation to MSMEs than domestic ownership.

Moreover, Table 5 column 1 shows that the dummy variable $\mathrm{MOE}_{\mathrm{i}, \mathrm{t-1}}$ has a significant negative effect on Credit_MSMEs $\mathrm{s}_{\mathrm{i}, \mathrm{t}}$ and with controlling capitalization, credit risk, and inflation, Table 2 column 2 also shows the consistent results. It shows that based on their mode of entry, banks with foreign ownership via greenfield have lower credit allocation to MSMEs than via takeover. The results for control variables based on Tables 4 and 5 are as follows. Capitalization ${ }_{i, t-1}$ have a significant positive effect on Credit_MSMEs ${ }_{i, t}$, while Credit_Risk $\mathrm{i}_{\mathrm{i},-1}$ have a significant negative effect on Credit MSMEs $_{i, t}$. It shows that when banks have higher capitalization, credit allocation to MSMEs increases, and when banks have higher credit risk, credit allocation to MSMEs decreases. Inflation $_{t-1}$ has no significant effect on Credit_MSMEs $\mathrm{s}_{\mathrm{i},}$

Table 4. Regressions of Credit MSMEs on Government and Foreign Ownership

\begin{tabular}{lcc}
\hline & Credit_MSMEs (1) & Credit_MSMEs (2) \\
\hline Constant & $0.356^{* * * *}$ & $0.361^{* * *}$ \\
Government & $(0.000)$ & $(0.000)$ \\
& $0.039^{*}$ & $0.051^{* *}$ \\
Foreign & $(0.099)$ & $(0.036)$ \\
& $-0.232^{* * *}$ & $-0.238^{* * *}$ \\
Capitalization & $(0.000)$ & $(0.000)$ \\
& & $0.108^{* *}$ \\
Credit_Risk & & $(0.017)$ \\
& & $-0.606^{* *}$ \\
Inflation & & $(0.049)$ \\
& & -0.336 \\
Observations & 686 & $(0.379)$ \\
$\mathrm{R}^{2}$ & 0.226 & 686 \\
F-Statistics & $99.849 * * *$ & 0.238 \\
& $(0.000)$ & $42.385^{* * *}$ \\
\hline Sign $* * * * *$
\end{tabular}

Sign $* * *, * *$, and $*$ present significance at the $1 \%, 5 \%$, and $10 \%$ level. Numbers in parenthesis is p-value
Table 5. Regressions of Credit MSMEs on Mode of Entry (MOE)

\begin{tabular}{lcc}
\hline & Credit_MSMEs (1) & Credit_MSMEs (2) \\
\hline Constant & $0.190^{* * *}$ & $0.191^{* * *}$ \\
& $(0.000)$ & $(0.000)$ \\
MOE & $-0.137^{* * *}$ & $-0.143^{* * *}$ \\
& $(0.000)$ & $(0.000)$ \\
Capitalization & & $0.071^{* *}$ \\
& & $(0.030)$ \\
Credit_Risk & & $-0.541^{* *}$ \\
& & $(0.049)$ \\
Inflation & & -0.147 \\
& & $(0.689)$ \\
Observations & 266 & 266 \\
R2 & 0.215 & 0.238 \\
F-Statistics & $72.256^{* * *}$ & $20.333 * * *$ \\
& $(0.000)$ & $(0.000)$
\end{tabular}

$\overline{\text { Sign } * * *, * * \text {, and } * \text { present significance at the } 1 \%, 5 \% \text {, and }}$ $10 \%$ level.

Numbers in parenthesis is p-value 


\section{DISCUSSIONS}

The results above indicate that banks with government ownership have higher credit allocation to MSMEs than non-government ownership. This is because these banks have social objectives other than maximizing their profits. The government will influence them to allocate more loans to MSMEs to give these entities adequate financing to expand their businesses and eventually will support the economies in the country. These banks also have better access to MSMEs, so they have the ability to give them more loans. This result is consistent with Berger et al. (2001, 2004) and Lubis, et al. (2015) who suggested a significant positive effect of government ownership on credit allocation to MSMEs.

Moreover, banks with foreign ownership have lower credit allocation to MSMEs than domestic ownership. This is because these banks have a screening advantage to evaluate borrowers that are not creditworthy, such as MSMEs who have high asymmetry information. These banks are also known for their high efficiency, so they will allocate their credit to transparent borrowers only because they are less risky and easy to evaluate based on the hard information they have and therefore this type of borrowers is not as costly as MSMEs. This result is consistent with Berger et al. (2001), Clarke et al. (2005, 2006), Mian (2006), Giannetti and Ongena $(2009,2012)$, and Gormley $(2010)$ who suggested a significant negative effect of foreign ownership on credit allocation to MSMEs.

In addition, banks with foreign ownership via greenfield have lower credit allocation to MSMEs than via takeover, because to analyze and monitor borrowers like MSMEs, banks need to use soft information, which could not be done by banks with foreign ownership via greenfield. Banks with foreign ownership via takeover have more advantages than greenfield because they got a customer base when they did a takeover on domestic banks. This customer base makes banks still have to fulfill credit demand from the old MSMEs customer, and they have the ability to do so because they could access both information, either soft or hard information. This result is consistent with DeGryse et al. (2012) and Claeys and Heinz (2014) who suggested a significant negative effect of mode of entry (greenfield) on credit allocation to MSMEs.

The results also show the effect of control variables, such as capitalization, credit risk, and inflation, on credit allocation to MSMEs. Capitalization has a significant positive effect on credit allocation to MSMEs. This is because banks with higher capitalization have enough capital to expand their credit to MSMEs, which take time and effort to evaluate them. These banks are willing to take more risks on this type of borrower because they have adequate buffers to cover this risk. Credit risk has a significant negative effect on credit allocation to MSMEs. This is because banks with higher credit risk are not healthy. They often suffer from financial distress and therefore will be required by government supervisors, depositors, and capital market investors to reduce their risk profile. Banks will reduce their credit allocation to MSMEs because this type of borrowers has high asymmetry information, so banks didn't want to take more risks by giving loans to borrowers that are hard to evaluate which could increase their non-performing loans (DeGryse et al., 2012). And for the macroeconomic variable, the author used the inflation rate. The results show that inflation has no significant effect on credit allocation to MSMEs. This is because even though higher inflation means a bad condition of the macroeconomic environment and might make banks less willing to allocate their credit to MSMEs (DeGryse et al. 2012), the decisions to allocate credit will still rely on the financial health of the bank itself. As long as banks are healthy, like adequate capital and low credit risk, banks will not significantly reduce their credit allocation to MSMEs.

\section{CONCLUSIONS}

Using a dataset from Indonesia, the author investigates the effect of bank ownership on credit allocation to MSMEs, controlling for capitalization, credit risk, and inflation rate. The main results can be summarized as follows. First, banks with government ownership have higher credit allocation to MSMEs than non-government ownership. This is consistent with the theory suggesting that these banks have the government's considerations to give subsidized loans to entities like MSMEs. Second, banks with foreign ownership have lower credit allocation to MSMEs than domestic ownership. This is consistent with the theory suggesting that these banks face disadvantages to collect soft information which is used to evaluate borrowers like MSMEs, so they prefer to allocate their credit to transparent borrowers. And based on the mode of entry, banks with foreign ownership via greenfield have lower credit allocation to MSMEs than via takeover. This is consistent with the theory suggesting that banks with foreign ownership via takeover have an incumbency advantage, which makes them get the ability to use soft information and allocate their credit to MSMEs from the old customers. 


\section{REFERENCES}

Althammer, W., Haselmann, R. 2011. Explaining Foreign Bank Entrance in Emerging Markets. Journal of Comparative Economics 39 (4), 486-498. https://doi.org/10.1016/j.jce.2011.03.002

Berger, A.N., Klapper, L.F. and Udell, G.F., 2001. The Ability of Banks to Lend to Informationally Opaque Small Businesses. Journal of Banking \& Finance, 25(12), pp.2127-2167.

Berger, A.N., Hasan, I. and Klapper, L.F., 2004. Further Evidence on the Link Between Finance and Growth: An International Analysis of Community Banking and Economic Performance. Journal of Financial Services Research, 25(2), pp.169-202.

Berger, A.N., Demirgüç-Kunt, A., Levine, R. and Haubrich, J.G., 2004. Bank Concentration and Competition: An Evolution in the Making. Journal of Money, Credit and Banking, pp.433-451.

Boustanifar, H., 2014. Information Acquisition, Foreign Bank Entry, and Credit Allocation. The Quarterly Review of Economics and Finance, 54(3), pp.324-336.

Cariola, A., Fasano, F., La Rocca, M. and Skatova, E., 2020. Environmental Sustainability Policies and the Value of Debt in EU SMEs: Empirical Evidence from the Energy Cector. Journal of Cleaner Production, 275, p. 123133.

Claeys, S., \& Hainz, C. 2014. Modes of Foreign Bank Entry on Information and Bank Lending Rates. Journal of Comparative Economics 42, 160-177. https://doi.org/10.1016/j.jce.2013.01.009

Clarke, G.R., Cull, R. and Peria, M.S.M., 2006. Foreign Bank Participation and Access to Credit Across Firms in Developing Countries. Journal of comparative economics, 34(4), pp.774-795. http://dx.doi.org/10.1016/j. jce.2006.08.001

Cull, R., Peria, M., Sánchez, S.M. and Clarke, G., 2002. Bank Lending to Small Businesses in Latin America: Does Bank Origin Matter?. The World Bank.

Çolak, M. S., \& Şenol, A. 2021. Bank Ownership and Lending Dynamics: Evidence from Turkish Banking Sector. International Review of Economics and Finance, 72(December 2020), 583-605. https://doi.org/10.1016/j. iref.2020.11.014

Degryse, H., O. Havrylchyk, E. Jurzyk. 2012. Foreign Bank Entry, Credit Allocation, and Lending Rates in Emering Markets: Empiral Evidence from Polland. Journal of Banking and Finance 36, 2949-2959. https:// doi.org/10.1016/j.jbankfin.2011.12.006

Dell'Ariccia, G. and Marquez, R., 2004. Information and Bank Credit Allocation. Journal of financial Economics, 72(1), pp.185-214. https://doi.org/10.1016/S0304-405X(03)00210-1

Detragiache, E., Tressel, T., Gupta, P. 2008. Foreign Banks in Poor Countries: Theory and Evidence. Journal of Finance 63 (5), 2123-2160. http://dx.doi.org/10.1111/j.1540-6261.2008.01392.x

Ding, N., Fung, H. G., \& Jia, J. 2020. Shadow Banking, Bank Ownership, and Bank Efficiency in China. Emerging Markets Finance and Trade, 56(15), 3785-3804. https://doi.org/10.1080/1540496X.2019.1579710

Eze, S. C., Awa, H. O., Chinedu-Eze, V. C. A., \& Bello, A. O. 2021. Demographic Determinants of Mobile Marketing Technology Adoption by Small and Medium Enterprises (SMEs) in Ekiti State, Nigeria. Humanities and Social Sciences Communications, 8(1), 1-11. https://doi.org/10.1057/s41599-021-00762-5

Financial Services Authority. 2017. Banking Industry Profile Report Quarter IV 2017. Jakarta, Indonesia: OJK

Giannetti, M., Ongena, S. 2009. Financial Integration and Firm Performance: Evidence from Foreign Bank Entry in Emerging Markets. Review of Finance 13, 181-223. https://doi.org/10.1093/rof/rfm019

Giannetti, M., Ongena, S. 2012. Lending by Example: Direct and Indirect Effects of Foreign Banks in Emerging Markets. Journal of International Economics 86 (1), 167-180. https://doi.org/10.1016/j.jinteco.2011.08.005

Gormley, T. 2010. The Impact of Foreign Bank Entry in Emerging Markets: Evidence from India. Journal of Financial Intermediation 19 (1), 26-51. https://doi.org/10.1016/j.jfi.2009.01.003

Gormley, T. 2014. Costly Information, Entry, and Credit Access. Journal of Economic Theory 154, 633-667. https://doi.org/10.1016/j.jet.2014.06.003

Indonesian Central Bank. 2013. Guidance Book for Central Government Content. Jakarta, Indonesia: BI

Indonesian Central Bank. 2015. Indonesian Central Bank Regulations No. 17/12/PBI/2015 about Amendments to Indonesian Central Bank Regulation No. 14/22/PBI/2012 about Provision of Loans or Financing by Commercial Banks and Technical Assistance in the Framework of Micro, Small, and Medium Enterprises Development

Indonesian Central Bank. 2017. Data of MSMEs Credit, Dec 2017. Jakarta, Indonesia: BI

Indonesian Government. 1999. Government Regulations of the Republic of Indonesia No. 29/1999 about Purchase of Shares of Commercial Banks

Lubis, A.W., Bustaman, Y. and Riyanti, R.S., 2015. Foreign Bank Entry and Credit Allocation to SMEs: Evidence from ASEAN Countries. Procedia-Social and Behavioral Sciences, 211, pp.1049-1056. 
Luu, H. N., Nguyen, L. Q. T., Vu, Q. H., \& Tuan, L. Q. 2020. Income Diversification and Financial Performance of Commercial Banks in Vietnam: Do Experience and Ownership Structure Matter? Review of Behavioral Finance, 12(3), 185-199. https://doi.org/10.1108/RBF-05-2019-0066

Mian, A. 2006. Distance Constraints: The Limits of Foreign Lending in Poor Economies. Journal of Finance 61 (3), 1465-1505. https://doi.org/10.1111/j.1540-6261.2006.00878.x

Sengupta, R. 2007. Foreign Entry and Bank Competition. Journal of Financial Economics 84, 502-528. https:// doi.org/10.1016/j.jfineco.2006.04.002 